physics. He was awarded his doctorate in 1928, and returned to Australia in 1929, to carry out research for the Radio Research Board, under Sir John Madsen. He returned to England in 1931 and became in succession lecturer in physics at Nottingham, Leicester and Birmingham. During the War he was in charge of a radar school under the Ministry of Aircraft Production. Prof. Huxley returned to Australia ten years ago to take the chair of physics at the University of Adelaide. $\mathrm{H}_{\Theta}$ is a member of the Councils of the Australian National University and the University of Adelaide. He has been associated with the Commonwealth Scientific and Industrial Research Organization through his chairmanship of the National Standards Commission and the Radio Research Board. He was a Foundation Fellow of the Australian Academy of Science, and is now the Academy's secretary (physical sciences). He is keenly interested in educational matters, being chairman of his University's Education Committee, and patron of the Science Teachers Association of South Australia.

Mr. G. B. Gresford

Two changes are also announced in the top administration of the Commonwealth Scientific and Industrial Research Organization. Mr. Guy B. Gresford has been appointed secretary and Mr. Walter Ires, executive officer. Mr. Gresford was educated at Trinity College, University of Melbourne. He joined the Organization in 1942. During the period 1943-46 he was in England on the staff of the Australian Scientific Liaison Office in London. $\mathrm{He}$ became assistant secretary of the Commonwealth Scientific and Industrial Research Organization in 1946 and research secretary (physical sciences) in 1952. In $1957, \mathrm{Mr}$. Gresford went to the United States on a Commonwealth Fund Fellowship, studying at the Harvard School of Public Administration and at the National Science Foundation in Washington.

Mr. W. ives

Mr. Ives graduated in economics at the University of Sydney. During the War he was with the Department of War Organization of Industry, and transferred later to the Department of Postwar Reconstruction. He joined the Commonwealth Scientific and Industrial Research Organization in $\mathbf{1 9 4 6}$ as technical secretary of the Division of Plant Industry. He became assistant secretary of the Organization in 1950 and research secretary (biological sciences) in 1952. During 1954-56 he was chief scientific liaison officer at the Anstralian Scientific Liaison Office in London.

\section{British Antarctic Party}

The third party of scientists and technicians of the Falkland Islands Dependencies Survey left Southampton on December 18 for the Antarctic aboard the Danish polar-exploration vessel, M.V. Kista Dan. Sir Vivian Fuchs, director of the Survey, flies from London on January 4 and joins the Kista Dan at Montevideo, where the vessel will take aboard two aireraft. These will be assembled at the ice edge to help in re-opening the Survey's southernmost base on Stonington Island (closed in March this year because of difficult ice conditions). Sir Vivian will take personal charge of this and allied operations and expects to be in the Antarctic for the rest of the summer season. The aircraft that will be used by the Falkland Islands Dependencies Survey will also support British exploration teams travelling south of Marguerite Bay. They will be operated by a Royal Air Force team of five. The Falkland Islands Dependencies Survey has maintained bases on the coast of Graham Land and nearby islands for fifteen years. At the bases, between 80 and 90 scientists and technicians spend periods of up to two years carrying out a regular programme of surveys, research and meteorological work. In January this year the Survey took over the base at Halley Bay (Coats Land) set up by the Royal Society expedition of 1955 as part of Britain's contribution to the International Geophysical Year, following the British Government's decision that scientific work should be continued there. Every antarctic summer, between November and March, the sea ice clears sufficiently for specially-built vessels to make the difficult voyage to Britain's Antarctic bases with relief staff and supplies. M.V. Kista Dan has been chartered by the Falkland Islands Dependencies Survey this season to supplement the work of its own vessels, R.R.S.'s John Biscoe and Shackleton. The former is expected to take part in the re-opening of the base on Stoning. ton Island after she has relieved the Halley Bay base

\section{Nigerian College of Arts, Science and Technology.}

More than $\$ 85,000$ was made available for the Nigerian College of Arts, Science and Technology among grants and loans approved in November under the Colonial Development and Welfare Acts. Four grants were approved for the building programme of the College- $£ 22,500$ for a library and $£ 15,322$ for a 30 -man hostel at its Zaria branch, and $£ 18,750$ for a library and $£ 28,584$ for a hostel block and two link blocks to accommodate 54 students at Ibadan. This brings to $£ 1,087,719$ the total made available for the development of the College sinee the first grant was approved in 1950. The College was established by the Nigerian Government as an autonomous federal institution, with branches at Enugu, Ibadan and Zaria, to share with University College, Ibadan, the task of providing higher education in the territory. It trains students in arts and science subjects leading to the United Kingdom General Certificate of Education (Advanced Level) and provides full professional courses leading to the examinations of appropriate professional bodies in Britain or to college diplomas, and certificate and other courses. The College is fully residential and it is hoped that by 1962 it will accommodate up to 1,250 students in its three branches. Total enrolment in the 1958-59 academic year was 875 students.

\section{New Research Laboratories of Messrs. John and \\ E. Sturge}

NEw laboratories for organic and biochemical research work have been opened at Wheeleys Road, Birmingham, by John and E. Sturge, Ltd., as part of a plan to centralize the company's research work. One of the main activities will be fundamental research on fermentation problems, particularly in connexion with the microbiological production of citric acid, involving a close study of the biochemical and chemical aspects of the life-cycle of Aspergillus niger and the undertaking of an extensive mutation programme. The laboratories include an instrument room maintained at $20^{\circ} \mathrm{C}$., a special cold room for enzyme manipulation in which the temperature can be kept down to $0^{\circ} \mathrm{C}$. indefinitely, and sterile airconditioned rooms to facilitate the handling of micro- 